\title{
Does evaporation paradox exist in China?
}

\author{
Z. T. Cong, D. W. Yang, and G. H. Ni \\ State Key Laboratory of Hydroscience and Engineering, Department of Hydraulic Engineering, Tsinghua University, \\ Beijing 100084, China
}

Received: 3 July 2008 - Published in Hydrol. Earth Syst. Sci. Discuss.: 4 August 2008

Revised: 26 November 2008 - Accepted: 6 March 2009 - Published: 18 March 2009

\begin{abstract}
One expected consequence of global warming is the increase in evaporation. However, lots of observations show that the rate of evaporation from open pans of water has been steadily decreasing all over the world in the past 50 years. The contrast between expectation and observation is called "evaporation paradox". Based on data from 317 weather stations in China from 1956 to 2005, the trends of pan evaporation and air temperature were obtained and evaporation paradox was analyzed. The conclusions include: (1) From 1956 to 2005, pan evaporation paradox existed in China as a whole while pan evaporation kept decreasing and air temperature became warmer and warmer, but it does not apply to Northeast and Southeast China; (2) From 1956 to 1985, pan evaporation paradox existed narrowly as a whole with unobvious climate warming trend, but it does not apply to Northeast China; (3) From 1986 to 2005, in the past 20 years, pan evaporation paradox did not exist for the whole period while pan evaporation kept increasing, although it existed in South China. Furthermore, the trend of other weather factors including sunshine duration, windspeed, humidity and vapor pressure deficit, and their relations with pan evaporation are discussed. As a result, it can be concluded that pan evaporation decreasing is caused by the decreasing in radiation and wind speed before 1985 and pan evaporation increasing is caused by the decreasing in vapor pressure deficit due to strong warming after 1986. With the Budyko curve, it can be concluded that the actual evaporation decreased in the former 30 years and increased in the latter 20 year for the whole China.
\end{abstract}

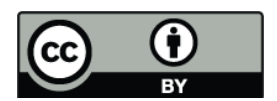

Correspondence to: Z. T. Cong (congzht@ @singhua.edu.cn)

\section{Introduction}

Terrestrial evapotranspiration contributes to $2 / 3$ of annual precipitation, or equivalent amount of twice of total surface runoff (Chahine, 1992; Brutsaert, 2005; Oki et al., 2006). At the same time, evapotranspiration plays an important role in the global energy budget. Therefore, changes of evapotranspiration have a great impact on global hydrologic cycle and energy budget.

Global warming has become a popular topic for governments and general public. It is reported that the surface temperature of the Earth was increasing at a rate of about $0.13^{\circ}$ per decade over the past 50 years (IPCC, 2007). One expects that global warming tends to make the air near the Earth surface drier and results in an increase in the rate of evaporation from terrestrial open water bodies. This increase would cause the scarcity of water resources worse, as predicted by some studies of climate change (Yao et al., 1997; Chattopadhyay et al., 1997; Brutsaert et al., 1998).

However, lots of observations show that the rate of pan evaporation had been consistently decreasing throughout the world over the past 50 years. This phenomenon was firstly reported by Peterson et al. (1995). Then it is found that similar trends widely present in India (Chattopadhyay et al., 1997), Venezuela (Quintana-Gomez et al., 1998), China (Liu et al., 2004), Italy (Moonen et al., 2002), Australia (Roderick et al., 2004), Japan (Asanuma et al., 2004), Thailand (Tebakari et al., 2005), New Zealand (Roderick et al., 2005) and Canada (Burn et al., 2006). The contrast between expected and observed trends of pan evaporation rate is called "pan evaporation paradox" or "evaporation paradox" (Roderick et al., 2002). Besides, a falling trend of reference evapotranspiration was also noticed by Chattopadhyay et al. (1997), Thomas (2000) and Roderick et al. (2004). Gifford et al. (2007) has made an excellent discussion on this topic.

Published by Copernicus Publications on behalf of the European Geosciences Union. 
What caused the decrease in pan evaporation rate and reference evapotranspiration? Possible reasons include: (1) decreasing sunlight due to increase in cloud coverage (Peterson et al., 1995; Roderick et al., 2002) and aerosol concentration (Stanhill et al., 2001); (2) decreasing vapor pressure deficit due to increasing air humidity (Chattopadhyay et al., 1997); and (3) decreasing wind speed due to monsoon change (Cohen et al., 2002). Decreasing in solar radiation or sunlight, referred as global dimming, could be the primary cause but this trend changed to the reverse direction in 1980s (Wild et al., 2005; Pinker et al., 2005).

It is debatable whether a decreasing pan or reference evaporation rate indicates decrease of actual evapotranspiration. A proportional relation between potential evaporation and actual evaporation rates is generally assumed in hydrological models, especially in models for crop evapotranspiration, such as FAO-56, in which a crop coefficient is introduced for conversion from reference evaporation rates to actual evaporation rates (Allen et al., 1998). Peterson et al. (1995) also concluded that a decreasing pan evaporation rate indicates decrease in actual evaporation. Supporting evidences for this opinion include increasing runoff coefficients observed in former Soviet Union and the United States over the past 20 years. However, Bouchet et al. (1963) found that there was a complementary relation between potential evaporation and actual evaporation, then Morton $(1976,1983)$ proposed CRAE (Complementary Relationship Areal Evapotranspiration) model. Complementary relationship was validated in some basins (Brown et al., 2001; Yue et al., 2003). Brutsaert et al. (1998) concluded that decrease in pan evaporation indicated an increase in actual evaporation from the surrounding non-humid environment, which indicated that actual evaporation and pan evaporation exhibited a complementary relationship rather than proportional one. Sartori (2006) suggested that water storage in atmosphere should be considered. Based on Budyko hypothesis (Budyko, 1963, 1974), Yang et al. $(2006,2007)$ presented a generalized description: the relationship was complementary with water control and proportional with energy control.

Variation of pan evaporation and reference evapotranspiration in China has been studied by some researchers. Thomas (2000) analyzed the time series (1954-1993) of PenmanMonteith evapotranspiration estimates from 65 stations. Liu et al. (2004) analyzed records of 85 stations from 1955 to 2000. Chen et al. (2005) analyzed 580 stations from 1951 to 2000. McVicar et al. (2005) analyzed the evaporation trend in the Loess Plateau. Ren et al. (2006) analyzed records of 600 stations from 1956 to 2000 . Wu et al. (2006) analyzed records of 616 stations from 1971 to 2000 . These studies suggest the existence of evaporation paradox in China as decreasing rates of pan evaporation and reference evapotranspiration were observed together with an increasing trend of air temperature.
During this study, 317 stations in China with complete data from 1956 to 2005 were selected from 751 stations. Trend analyses were conducted based on observations of pan evaporation, air temperature, sunshine duration, wind speed, humidity and vapor pressure deficit in different periods. The purpose of this study is to investigate evaporation paradox in China and get further understanding of the variation of pan evaporation.

\section{Data and methodology}

\subsection{Data}

Data used in this study include pan evaporation rates records from 709 stations from 1956 to 2005, which were collected from Climatic Data Center, National Meteorological Information Center, China Meteorological Administration, and other weather data from 751 stations released by China Meteorological Data Sharing Service System (http://cdc.cma.gov. $\mathrm{cn} /$ ). Only 317 stations have full records of all weather factors from 1956 to 2005 . We selected them for trend analysis. It is assumed that the selected stations are sufficient to characterize climate conditions throughout the study area.

\subsection{Methodolgy}

The arithmetic average over the 317 selected stations is taken to get the average of the whole country. In particular, linear regression was used to identify trends of climatic variables including pan evaporation, air temperature and windspeed. The nonparametric Mann-Kendall's test was applied for trend detection (Maidment et al, 1993) with a significance level $(\alpha)$ of $5 \%$. Then the stepwise regression method was used to analyze the significance to pan evaporation of independent variables and the Budyko curve was applied to discuss the relations between actual evaporation and potential evaporation.

The following equations were used to obtain vapor pressure deficit (Allen et al., 1998):

$$
\begin{aligned}
& e_{s}-e_{a}=e_{s}(1-\mathrm{RH}) \\
& e_{s}=6.11 \exp \left(\frac{17.27 T_{\text {mean }}}{T_{\text {mean }}+237.3}\right)
\end{aligned}
$$

Where, $\mathrm{e}_{s}=$ saturated vapor pressure in mbar; $\mathrm{e}_{a}=$ actual vapor pressure in mbar; $T_{\text {mean }}=$ annual average of daily mean air temperature in ${ }^{\circ}$; and $\mathrm{RH}=$ relative humidity $(\%)$.

\section{Results and discussions}

\subsection{Trends}

Figure 1 shows the arithmetic average of annual pan evaporation rates and annual average of daily mean air temperature based on data from those 317 stations. Pan evaporation 
Table 1. Trends of weather factors in China from 1956 to 2005.

\begin{tabular}{|c|c|c|c|c|c|c|c|c|c|}
\hline Item & Period & Average & Unit & Trend & Unit & $\begin{array}{l}\text { Increasing } \\
\text { Number }\end{array}$ & $\begin{array}{l}\text { Decreasing } \\
\text { Number }\end{array}$ & $\begin{array}{l}\text { Kendall test } \\
\text { in increasing }\end{array}$ & $\begin{array}{l}\text { Kendall test } \\
\text { in decreasing }\end{array}$ \\
\hline \multirow{2}{*}{$\begin{array}{l}\text { Annual pan } \\
\text { evaporation }\end{array}$} & 1956-2005 & 1662 & $\mathrm{~mm}$ & -19.3 & $\mathrm{~mm} / 10 \mathrm{a}$ & 122 & 195 & $44.3 \%$ & $65.6 \%$ \\
\hline & 1986-2005 & 1632 & $\mathrm{~mm}$ & 46.5 & $\mathrm{~mm} / 10 \mathrm{a}$ & 199 & 118 & $55.3 \%$ & $33.1 \%$ \\
\hline \multirow{2}{*}{$\begin{array}{l}\text { Daily maximum } \\
\text { air temperature }\end{array}$} & 1956-2005 & 18.6 & $\circ$ & 0.15 & $\circ / 10 \mathrm{a}$ & 293 & 24 & $62.8 \%$ & $12.5 \%$ \\
\hline & 1956-1985 & 18.4 & $\circ$ & -0.08 & $\circ / 10 \mathrm{a}$ & 98 & 219 & $35.7 \%$ & $26.5 \%$ \\
\hline \multirow{2}{*}{$\begin{array}{l}\text { Annual mean } \\
\text { air temperature }\end{array}$} & 1956-1985 & 12.6 & $\circ$ & 0.04 & $\circ / 10 \mathrm{a}$ & 167 & 150 & $12.6 \%$ & $12.0 \%$ \\
\hline & 1986-2005 & 13.2 & $\circ$ & 0.44 & $\circ / 10 \mathrm{a}$ & 304 & 13 & $71.7 \%$ & $15.4 \%$ \\
\hline \multirow{3}{*}{$\begin{array}{l}\text { Daily minimum } \\
\text { air temperature }\end{array}$} & 1956-2005 & 8.3 & $\circ$ & 0.31 & $\circ / 10 \mathrm{a}$ & 308 & 9 & $89.0 \%$ & $55.6 \%$ \\
\hline & 1956-1985 & 8.0 & $\circ$ & 0.12 & $\circ / 10 \mathrm{a}$ & 219 & 98 & $36.1 \%$ & $10.2 \%$ \\
\hline & 1986-2005 & 8.8 & $\circ$ & 0.49 & $\circ / 10 \mathrm{a}$ & 295 & 22 & $71.9 \%$ & $9.1 \%$ \\
\hline \multirow{2}{*}{$\begin{array}{l}\text { Annual sunshine } \\
\text { duration }\end{array}$} & 1956-1985 & 2276 & $\mathrm{~h}$ & -60.6 & $\mathrm{~h} / 10 \mathrm{a}$ & 61 & 256 & $18.0 \%$ & $57.4 \%$ \\
\hline & 1986-2005 & 2150 & $\mathrm{~h}$ & -18.1 & $\mathrm{~h} / 10 \mathrm{a}$ & 133 & 184 & $24.8 \%$ & $28.8 \%$ \\
\hline \multirow{3}{*}{$\begin{array}{l}\text { Annual mean } \\
\text { wind speed }\end{array}$} & 1956-2005 & 2.3 & $\mathrm{~m} / \mathrm{s}$ & -0.11 & $\mathrm{~m} / \mathrm{s} / 10 \mathrm{a}$ & 67 & 250 & $35.8 \%$ & $84.0 \%$ \\
\hline & 1956-1985 & 2.5 & $\mathrm{~m} / \mathrm{s}$ & -0.07 & $\mathrm{~m} / \mathrm{s} / 10 \mathrm{a}$ & 115 & 202 & $29.6 \%$ & $61.9 \%$ \\
\hline & 1986-2005 & 2.1 & $\mathrm{~m} / \mathrm{s}$ & -0.06 & $\mathrm{~m} / \mathrm{s} / 10 \mathrm{a}$ & 134 & 183 & $43.3 \%$ & $45.9 \%$ \\
\hline \multirow[t]{3}{*}{ Annual mean RH } & 1956-2005 & 67.4 & $\%$ & -0.20 & $\% / 10 \mathrm{a}$ & 108 & 209 & $37.0 \%$ & $49.8 \%$ \\
\hline & 1956-1985 & 67.6 & $\%$ & 0.00 & $\% / 10 \mathrm{a}$ & 173 & 144 & $24.9 \%$ & $27.8 \%$ \\
\hline & 1986-2005 & 67.2 & $\%$ & -0.91 & $\% / 10 \mathrm{a}$ & 83 & 234 & $9.6 \%$ & $35.9 \%$ \\
\hline \multirow{3}{*}{$\begin{array}{l}\text { Annual mean vapor } \\
\text { pressure deficit }\end{array}$} & 1956-2005 & 4.5 & hpa & 0.10 & $\mathrm{hpa} / 10 \mathrm{a}$ & 254 & 63 & $66.5 \%$ & $28.6 \%$ \\
\hline & 1956-1985 & 4.4 & hpa & -0.01 & hpa/10a & 157 & 160 & $28.7 \%$ & $29.4 \%$ \\
\hline & 1986-2005 & 4.7 & hpa & 0.29 & hpa/10a & 276 & 41 & $52.9 \%$ & $9.8 \%$ \\
\hline
\end{tabular}

presents a decreasing trend from 1956 to 1985 while air temperature increases; but pan evaporation appears increasing after 1986 with rapid increase in air temperature. Therefore, the 50 years period from 1956 to 2005 could be divided into two sections: a 30 years period from 1956 to 1985 and a 20 years period from 1986 to 2005 . Trends of analyzed climate variables are listed in Table 1.

\subsection{Evaporation paradox}

Over the past 50 years from 1956 to 2005, climate warming trend was obvious in China. Annual average of daily mean air temperature was increasing at a rate of $0.23^{\circ}$ per decade. Records of 306 stations out of the 317 selected stations showed an increasing trend, and $84.3 \%$ of them satisfied the nonparametric Mann-Kendall's test (Fig. 2a). Over the same period, pan evaporation appeared a decreasing trend. Annual pan evaporation was decreasing at a rate of $19.3 \mathrm{~mm}$ per decade. The decreasing trend was noticed at 195 stations (about $2 / 3$ of the selected stations) and $65.6 \%$ of them satisfied the nonparametric Mann-Kendall's test (Fig. 2b). At the same time, for 186 out of the 195 stations, air temperature

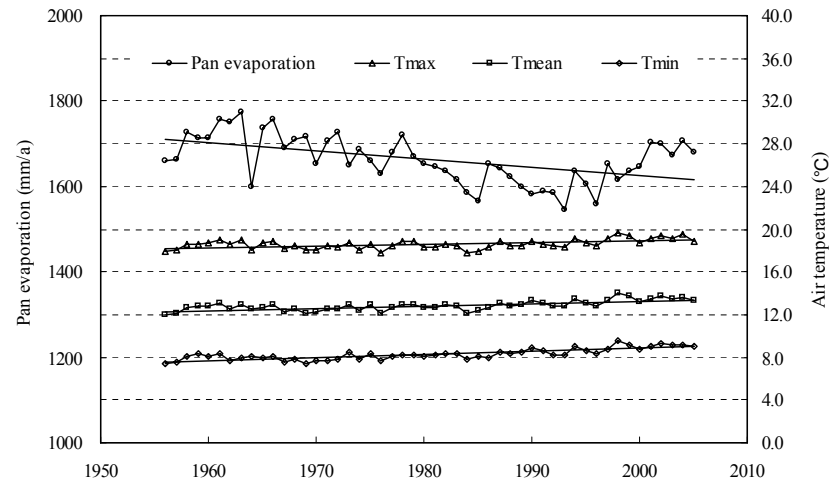

Fig. 1. Annual pan evaporation and annual mean air temperature from 1956 to 2005 .

was increasing. Therefore, we can conclude that evaporation paradox does exist in China in general.

Over the 30 years period before 1985, the climate warming trend was relatively weak. Annual average of daily mean air temperature was increasing at a rate of $0.04^{\circ}$ per 

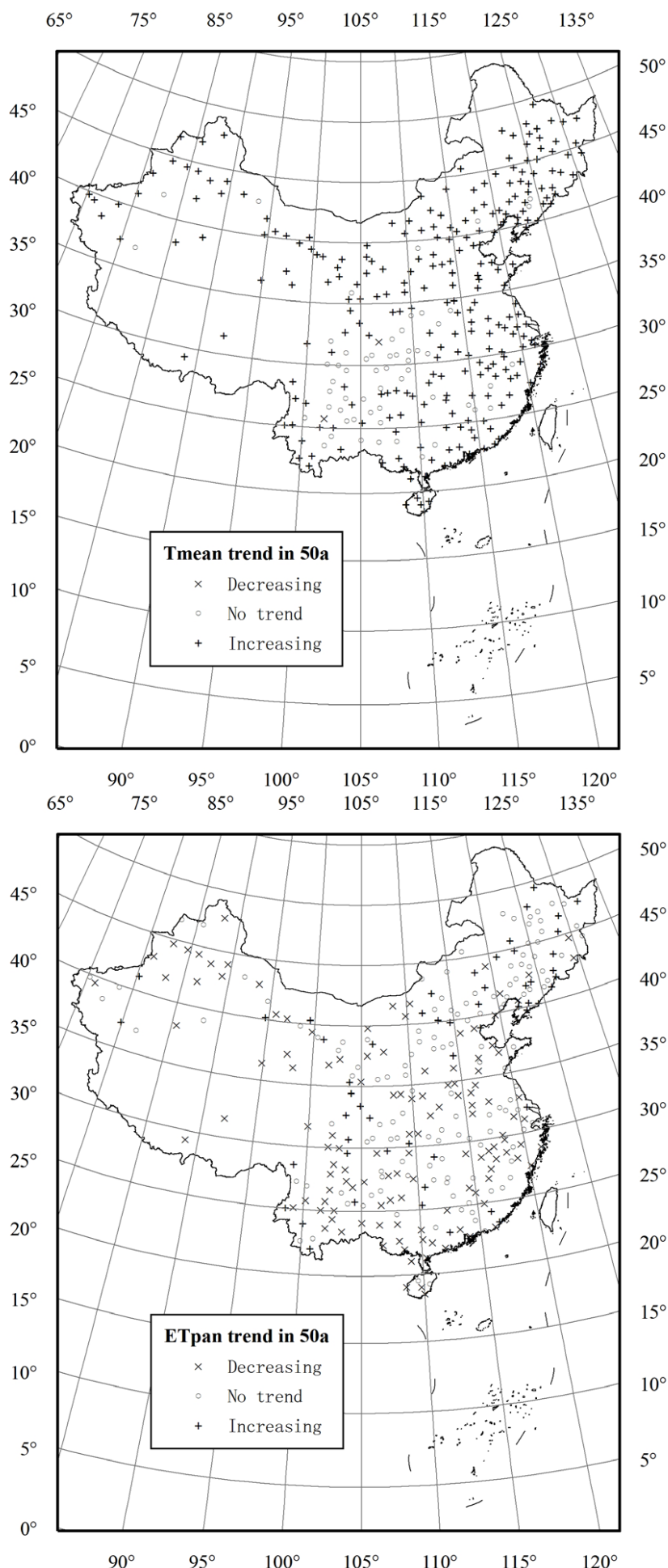

Fig. 2. Trends in the past 50 years from 1956 to 2005; (a) trends of annual mean air temperature, (b) trends of annual pan evaporation.
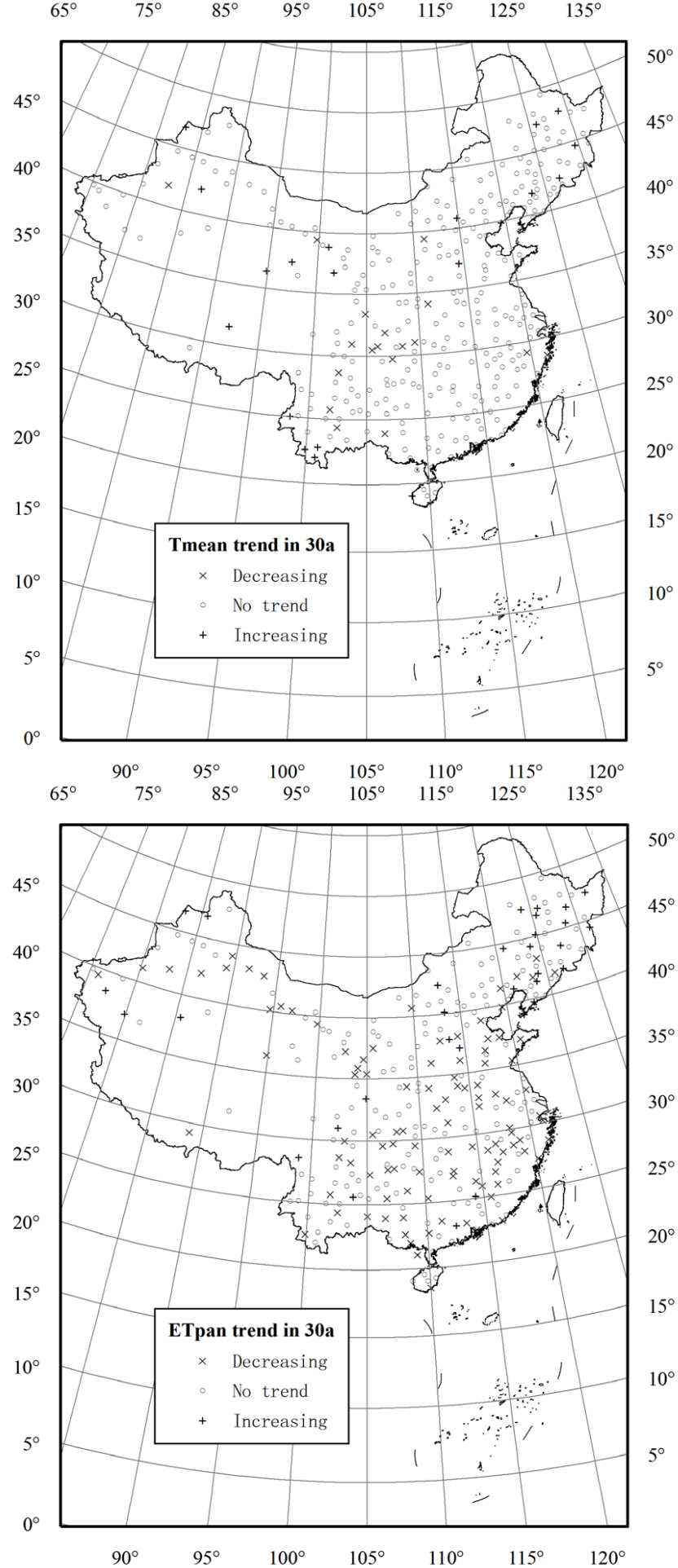

Fig. 3. Trends in the 30 years period before 1985; (a) trends of annual mean air temperature, (b) trends of annual pan evaporation. 

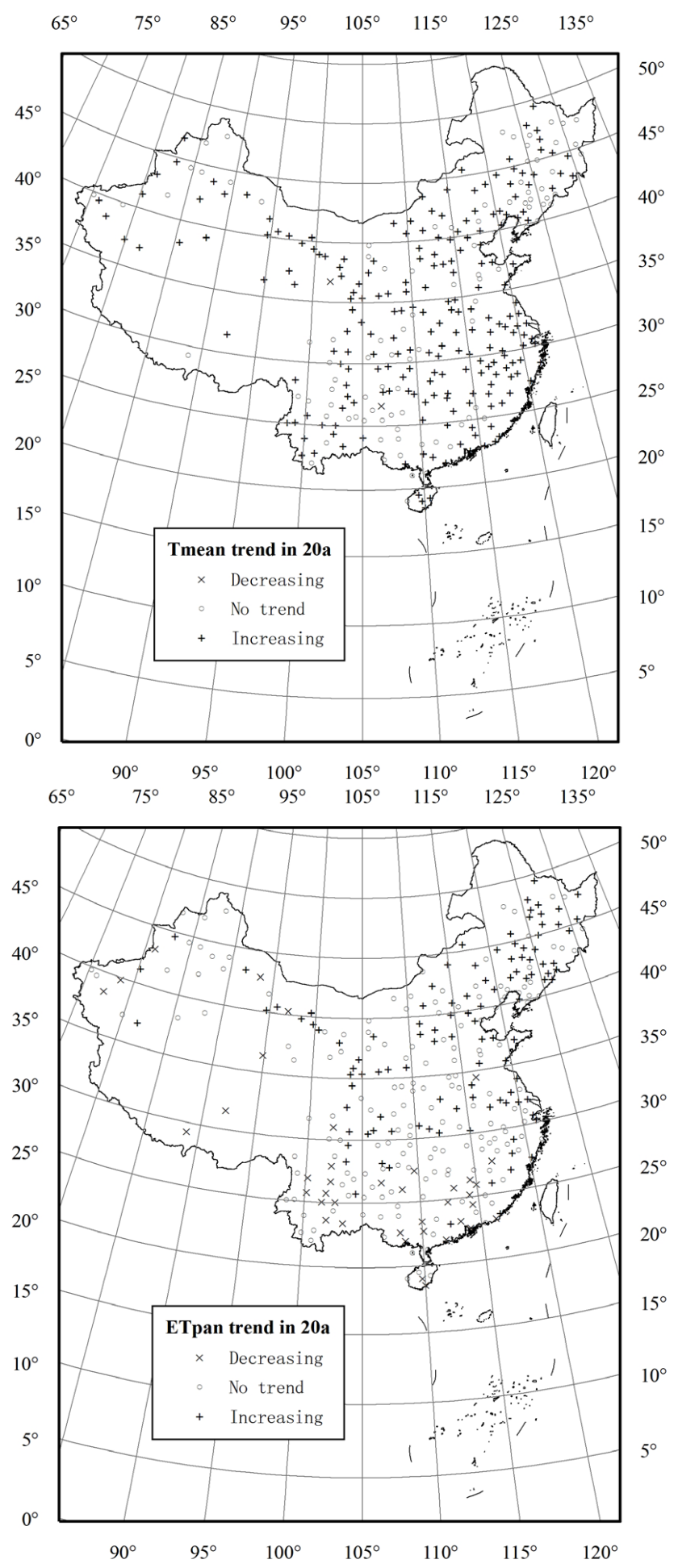

Fig. 4. Trends in the 20 years period after 1986; (a) trends of annual mean air temperature, (b) trends of annual pan evaporation. decade. Only 167 stations presented an increasing trend, and $12.6 \%$ of them satisfied the nonparametric Mann-Kendall's test (Fig. 3a). Over the same period, annual pan evaporation was decreasing at a rate of $35.7 \mathrm{~mm}$ per decade. 226 stations showed a decreasing trend, but only $46.9 \%$ of them satisfied the nonparametric Mann-Kendall's test (Fig. 3b). During this period, there were only 99 stations whose records supported evaporation paradox. Therefore, it might be debatable to think that evaporation paradox existed in China over the 30 years period before 1985 .

Over the 20 years period after 1986, climate warming trend was obvious. Annual average of daily mean air temperature was increasing at a rate of $0.44^{\circ}$ per decade. Records of 304 out of the selected 317 stations indicated an increasing trend, and $71.7 \%$ of them satisfied the nonparametric MannKendall's test (Fig. 4a). For the same period, pan evaporation was increasing at a rate of $46.5 \mathrm{~mm}$ per decade. An increasing trend existed at about $2 / 3$ of the selected stations (199 out of 317) and $55.3 \%$ of them satisfied the nonparametric Mann-Kendall's test (Fig. 4b). Accordingly, it may be concluded that evaporation paradox did not exist in China for the past 20 years after 1986 when pan evaporation was increasing.

From the spatial dimension, it can be found the universality for the evaporation paradox. In the 50 years period from 1956 to 2005, evaporation paradox existed in China expect Northeast and Southwest areas, where pan evaporation increased while the climate became warmer (see Fig. 2). In the 30 years period before 1985, evaporation paradox existed in China expect northeast area (where pan evaporation increased while the climate became warmer) and Southwest area (where the air temperature decreased with the decrease in pan evaporation) (see Fig. 3). In the 20 years period after 1986, evaporation paradox did not exist in China as a whole expect South China, where pan evaporation decreased while the climate became warmer (see Fig. 4).

In summary, it can be concluded that pan evaporation paradox exists in China as a whole (see Fig. 1), but it is not universal in either timing or spatial dimension.

\subsection{Relations between evaporation and other weather fac- tors}

\subsubsection{General information}

Evaporation, including pan evaporation, potential evaporation and actual evapotranspiration, is influenced by solar radiation, air temperature, wind speed, vapor pressure deficit, etc. When using standard Penman-Monteith function presented by Allen et al. (1998), reference evapotranspiration can be calculated with radiation, wind speed, air temperature and vapor pressure deficit. As solar radiation observations were not available for this study, radiation was estimated based on sunshine duration according to Allen et al. (1998). Relations between evaporation and sunshine duration, wind 
Table 2. Relations between trends of pan evaporation and that of other weather factors.

\begin{tabular}{lccccccccc}
\hline Weather factors & Period & \multicolumn{3}{c}{$\begin{array}{c}\text { Decreasing in pan evaporation with } \\
\text { its decreasing }\end{array}$} & \multicolumn{2}{c}{$\begin{array}{l}\text { Increasing in pan evaporation with } \\
\text { its inceasing }\end{array}$} & its decreasing & its increasing \\
\hline Sunshine duration & $1956-2005$ & 170 & $54 \%$ & 25 & $8 \%$ & 101 & $32 \%$ & 21 & $7 \%$ \\
& $1956-1985$ & 190 & $60 \%$ & 36 & $11 \%$ & 66 & $21 \%$ & 25 & $8 \%$ \\
& $1986-2005$ & 73 & $23 \%$ & 45 & $14 \%$ & 111 & $35 \%$ & 88 & $28 \%$ \\
Wind speed & $1956-2005$ & 163 & $51 \%$ & 32 & $10 \%$ & 87 & $27 \%$ & 35 & $11 \%$ \\
& $1956-1985$ & 157 & $50 \%$ & 69 & $22 \%$ & 45 & $14 \%$ & 46 & $15 \%$ \\
& $1986-2005$ & 76 & $24 \%$ & 42 & $13 \%$ & 107 & $34 \%$ & 92 & $29 \%$ \\
Vapor pressure deficit & $1956-2005$ & 51 & $16 \%$ & 144 & $45 \%$ & 12 & $4 \%$ & 110 & $35 \%$ \\
& $1956-1985$ & 139 & $44 \%$ & 87 & $27 \%$ & 21 & $7 \%$ & 70 & $22 \%$ \\
Humidity & $1986-2005$ & 25 & $8 \%$ & 93 & $29 \%$ & 16 & $5 \%$ & 183 & $58 \%$ \\
& $1956-2005$ & 109 & $34 \%$ & 86 & $27 \%$ & 100 & $32 \%$ & 22 & $7 \%$ \\
& $1956-1985$ & 81 & $26 \%$ & 145 & $46 \%$ & 63 & $20 \%$ & 28 & $9 \%$ \\
& $1986-2005$ & 76 & $24 \%$ & 42 & $13 \%$ & 158 & $50 \%$ & 41 & $13 \%$ \\
\hline
\end{tabular}

Note: In this table, a number means the number of stations where pan evaporation decreased/increased when one weather factor decreased/increased; a percentage means the percentage of these stations in the total 317 stations. For example, "170" (Row 3, Column 3) means that there are 170 stations where sunshine duration decreased and pan evaporation decreased from 1956 to 2005.
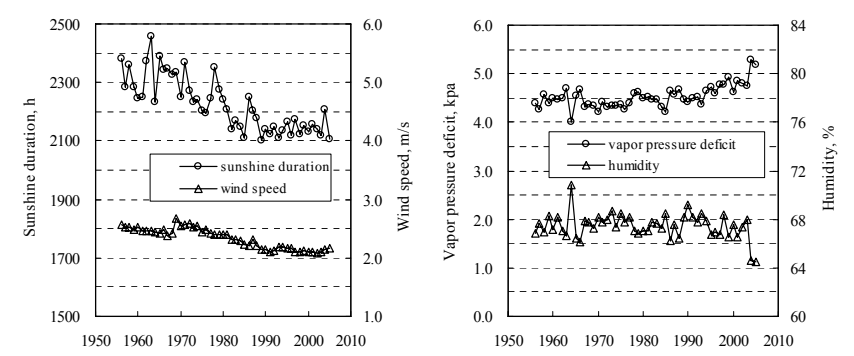

Fig. 5. Weather factors in the past 50 years - (a) sunshine duration and wind speed; (b) humidity and vapor pressure deficit.

speed and vapor pressure deficit were discussed. Trends of these weather factors are shown in Fig. 5 and relations between trends of pan evaporation and that of other weather factors are presented in Table 2.

A correlation analysis was conducted between pan evaporation and other weather factors. Correlation coefficients based on records from the 317 stations in different periods are shown in Table 3. These correlations are discussed in detail below. Furthermore, the stepwise regression method was used to analyze the significance to pan evaporation of independent variables in different periods, and results can be found in Table 4.

\subsubsection{Sunshine duration}

We got a positive correlation between pan evaporation and sunshine duration, which is reasonable as radiation is energy source for evaporation. As shown in Table 3, relations in different periods are similar and about $2 / 3$ of those stations have a coefficient which is greater than 0.3 .
From 1956 to 2005, sunshine duration data appeared a decreasing trend. A decreasing trend existed at more than half of the 317 stations for both pan evaporation and sunshine duration. The decreasing trend of sunshine duration may be caused by larger cloudy coverage and increasing aerosol concentration. However, when pan evaporation became increasing after 1986, sunshine duration still appeared a decreasing trend, even though this trend became weaker (Tables 1 and 2).

\subsubsection{Wind speed}

From 1956 to 2005, evaporation decreased with the decrease of wind speed, which can be represented as a positive correlation relation with average coefficient of 0.27 (Table 3). But the proportion relation became weaken after 1986 because of increasing in evaporation with decreasing in wind speed. The decreasing wind speed may be a result of the monsoon weakening (Xu et al., 2006) or urbanization over the past 50 years (Ren et al., 2008). Wind speed has kept decreasing after 1986.

\subsubsection{Humidity and vapor pressure deficit}

According to Eq. (2), saturated vapor pressure would increase for given humidity when air temperature increases. As a result, vapor pressure deficit would increase. Over the past 50 years, humidity changes in China were minor, while increase of vapor pressure deficit was found (Table 1). According to standard Penman-Monteith function (Allen et al., 1998), increasing vapor pressure deficit would result in increase of pan evaporation. However, pan evaporation over the past 50 years did not increase consistently with the increase of vapor pressure deficit, which may suggest that 
Table 3. Correlation coefficients between pan evaporation and other weather factors.

\begin{tabular}{|c|c|c|c|c|}
\hline \multicolumn{5}{|l|}{ From 1956 to 2005} \\
\hline Weather factors & $\begin{array}{l}\text { Coefficient } \\
\text { of average }\end{array}$ & $\begin{array}{l}\text { Average } \\
\text { coefficient }\end{array}$ & $\begin{array}{l}\text { Number of stations with } \\
\text { coefficient greater than } 0.3\end{array}$ & $\begin{array}{l}\text { Number of stations with } \\
\text { coefficient less than }-0.3\end{array}$ \\
\hline Mean air temperature & -0.02 & 0.24 & 139 & 14 \\
\hline Max air temperature & 0.25 & 0.36 & 207 & 4 \\
\hline Min air temperature & -0.23 & 0.05 & 67 & 40 \\
\hline Sunshine duration & 0.75 & 0.37 & 189 & 1 \\
\hline Wind speed & 0.53 & 0.27 & 152 & 8 \\
\hline Humidity & -0.36 & -0.49 & 0 & 261 \\
\hline Precipitation & -0.33 & -0.36 & 0 & 212 \\
\hline Vapor pressure deficit & 0.19 & 0.47 & 247 & 2 \\
\hline \multicolumn{5}{|l|}{ From 1956 to 1985} \\
\hline Weather factors & $\begin{array}{l}\text { Coefficient } \\
\text { of average }\end{array}$ & $\begin{array}{l}\text { Average } \\
\text { coefficient }\end{array}$ & $\begin{array}{l}\text { Number of stations with } \\
\text { coefficient greater than } 0.3\end{array}$ & $\begin{array}{l}\text { Number of stations with } \\
\text { coefficient less than }-0.3\end{array}$ \\
\hline Mean air temperature & 0.35 & 0.38 & 220 & 1 \\
\hline Max air temperature & 0.68 & 0.49 & 260 & 0 \\
\hline Min air temperature & -0.08 & 0.09 & 63 & 17 \\
\hline Sunshine duration & 0.79 & 0.41 & 224 & 6 \\
\hline Wind speed & 0.51 & 0.30 & 175 & 8 \\
\hline Humidity & -0.48 & -0.58 & 0 & 291 \\
\hline Precipitation & -0.42 & -0.40 & 1 & 229 \\
\hline Vapor pressure deficit & 0.61 & 0.60 & 295 & 0 \\
\hline \multicolumn{5}{|l|}{ From 1986 to 2005} \\
\hline Weather factors & $\begin{array}{l}\text { Coefficient } \\
\text { of average }\end{array}$ & $\begin{array}{l}\text { Average } \\
\text { coefficient }\end{array}$ & $\begin{array}{l}\text { Number of stations with } \\
\text { coefficient greater than } 0.3\end{array}$ & $\begin{array}{l}\text { Number of stations with } \\
\text { coefficient less than }-0.3\end{array}$ \\
\hline Mean air temperature & 0.56 & 0.37 & 206 & 7 \\
\hline Max air temperature & 0.61 & 0.42 & 230 & 7 \\
\hline Min air temperature & 0.52 & 0.21 & 137 & 22 \\
\hline Sunshine duration & 0.37 & 0.34 & 193 & 14 \\
\hline Wind speed & -0.19 & 0.16 & 109 & 25 \\
\hline Humidity & -0.60 & -0.50 & 3 & 254 \\
\hline Precipitation & -0.32 & -40.35 & 1 & 205 \\
\hline Vapor pressure deficit & 0.76 & 0.54 & 264 & 5 \\
\hline
\end{tabular}

effects of increasing vapor pressure deficit on pan evaporation are less than effects of decrease in radiation and wind speed. After 1986, vapor pressure deficit increased obviously due to the strong trend of climate warming, and its effects on pan evaporation could become more significant than the influence of decrease in radiation and wind speed, which contributed to the increase of pan evaporation.

\subsubsection{Stepwise regression analysis}

Furthermore, stepwise regression method was used to analyze the significance to pan evaporation of the independent variables. From 1956 to 1985, pan evaporation decreased with the decreasing in daily maximum air temperature and the decreasing in wind speed; from 1986 to 2005, pan evap- oration increased with the increasing in daily maximum air temperature and the decreasing in precipitation; from 1956 to 2005, pan evaporation decreased under the integrated influence of sunshine duration, maximum air temperature, wind speed and precipitation (Tables 1 and 4). Comparing the standardized coefficients in Table 4 , it can be found that the maximum air temperature made the most significant influence on pan evaporation trend in all the three periods, which is consistent with the common sense that the evaporation will increase with the temperature increasing. The wind speed, decreasing obviously from 1956 to 1985 but not obviously from 1986 to 2005 , became the significant influence factor on pan evaporation in the former 30 years. Contrary to wind speed, the precipitation changed obviously from 1986 to 2005 but not obviously from 1956 to 1985 and became the 
Table 4. Results of stepwise regression.

\begin{tabular}{llcc}
\hline Period & $\begin{array}{l}\text { Variables } \\
\text { entered }\end{array}$ & $\begin{array}{c}\text { Unstandardized } \\
\text { Coefficients }\end{array}$ & $\begin{array}{c}\text { Standardized } \\
\text { Coefficients }\end{array}$ \\
\hline \multirow{1}{*}{$1956-2005$} & (Constant) & -451.634 & \\
& Sunshine duration & 0.183 & 0.302 \\
& Max air temperature & 80.308 & 0.636 \\
& Windspeed & 205.245 & 0.629 \\
& Precipitation & -0.307 & -0.259 \\
$1956-1985$ & (Constant) & -676.51 & \\
& Max air temperature & 156.56 & 1.044 \\
& Min air temperature & -105.46 & -0.608 \\
& Windspeed & 128.75 & 0.234 \\
1986-2005 & (Constant) & 477.02 & \\
& Max air temperature & 90.35 & 0.803 \\
& Precipitation & -0.64 & -0.587 \\
\hline
\end{tabular}

Note: Stepwise (Criteria: Probability-of-F-to-enter $<=.100$, Probability-of-F-to-remove $>=.101$ ).

significant influence factor on pan evaporation in the latter 20 years. For the whole 50 years, the maximum air temperature, the wind speed and the precipitation all became the significant influence factors on pan evaporation.

\subsubsection{Summary}

Before 1985, pan evaporation decreased with radiation decreasing, windspeed decreasing and vapor pressure deficit increasing, so evaporation is mainly controlled by energy condition. After 1986, pan evaporation increased with radiation decreasing, windspeed decreasing and vapor pressure deficit increasing, so evaporation is mainly controlled by water condition. For the past 50 years, pan evaporation decreased with radiation decreasing, windspeed decreasing and vapor pressure deficit increasing.

3.4 Relations between actual evaporation and potential evaporation

For the yearly scale, Budyko $(1963,1974)$ presented a curve to describe the relation of actual evaporation, potential evaporation and precipitation. Based on this curve, the potential evaporation decreases and the actual evaporation increases with the precipitation increasing (seeing Fig. 6). However, this only occurs when the energy (i.e. radiation) is fixed. That is to say that the actual evaporation would increase from 1956 to 1985 then decreased in the past 20 years in contradiction to the trend of pan evaporation if the sunshine duration, the air temperature, and the wind speed had no change. In fact, the energy condition changed in the past 50 years, which can be described with the change of Budyko curve. From 1956 to 1985 (in Fig. 6a), the potential evaporation decreased, which can be supposed that the relation changed from curve 1 to curve 2, and the precipitation decreased from $\mathrm{P} 1$ to $\mathrm{P} 2$ at the same time, so both the pan evaporation and the actual evaporation decreased in this period. From 1986 to

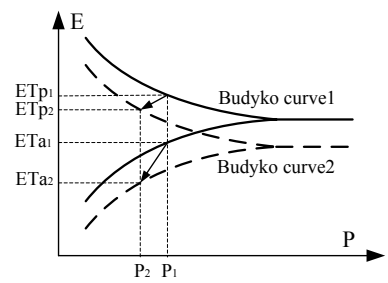

A From 1956 to 1985

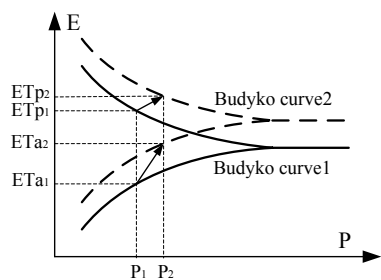

B From 1986 to 2005
Fig. 6. Hydrological trend in China during the past 50 years - (a) from 1956 to 1985; (b) from 1986 to 2005,

2005 (in Fig. 6b), the potential evaporation increased, which can be supposed that the relation changed from curve 1 to curve 2, and the precipitation increased from P1 to P2 at the same time, so both the pan evaporation and the actual evaporation increased in this period. Therefore, it can be conclude that the actual evaporation decreased in the former 30 years and increased in the latter 20 year for the whole China. These discussions are mainly theoretic and qualitative and further quantitative analysis should be carried out for each catchment in this country.

\section{Conclusions}

Based on weather data of the 317 stations in China from 1956 to 2005 and the trend analysis, we can get these conclusions:

(1) Pan evaporation paradox exists in China as a whole while the climate became warmer and warmer and pan evaporation kept decreasing in the past 50 years. But pan evaporation paradox did not exist in Northeast and Southwest China, where pan evaporation increased while the climate became warmer and warmer in the same period.

(2) From 1956 to 1985, the trend of climate warming is not obvious while pan evaporation decreased, so pan evaporation paradox existed narrowly as a whole. In the same period, the paradox did not exist in Northeast China (where pan evaporation increased while the climate became warmer and warmer) and Southwest China (where air temperature decreased with the decrease in pan evaporation).

(3) From 1986 to 2005, the warming is obvious, but pan evaporation increased, so pan evaporation paradox did not exist in China as a whole for the past 20 years. In the same period, pan evaporation paradox existed in South China, where pan evaporation decreased while the climate became warmer and warmer.

(4) Before 1985, despite vapor pressure deficit kept increasing, radiation decreasing and windspeed decreasing caused pan evaporation to decrease, so evaporation was mainly controlled by energy condition. After 1986, despite radiation and wind speed kept decreasing, vapor pressure deficit increasing caused pan evaporation to increase, so evaporation was mainly controlled by water condition. 
(5) The actual evaporation decreased in the former 30 years and increased in the latter 20 year for the whole China.

Acknowledgements. This study is supported by the National Science Foundation of China grants 50509011 and 50721140161.

Edited by: A. Shamseldin

\section{References}

Allen, R. G., Pereira, L. S., Raes, D., and Smith, M. (Eds.): Crop evapotranspiration, in: Guidelines for computing crop water requirements, FAO Irrigation and Drainage Paper 56, FAO, Rome, 1998.

Asanuma, J. and Kamimura, H.: Long-term trend of pan evaporation measurements in Japan and its relevance to the variability of the hydrological cycle, online available at: http://www.suiri. tsukuba.ac.jp/ asanuma/publications/proc_e.html, 2004.

Bouchet, R. J.: Evapotranspiration reele et potentielle, signification climateque, Int. Ass. Sci. Hydrol. Proc. Berkeley, CA, USA, Symp., Publ. 62, 134-142, 1963.

Brown, T. C. and Claessens, L. H. J. M.: The complementary relationship in estimation of regional evapotranspiration: The Complementary Relationship Areal Evapotranspiration and Advection-Aridity models, Water Resour. Res, 37(5), 13671387, 2001.

Brutsaert, W. (Ed.): Hydrology: an Introduction, Cambridge University Press, New York, NY, USA, 2-4, 2005.

Brutsaert, W. and Parlange M. B.: Hydrologic cycle explains the evaporation paradox, Nature, 396, 30, 1998.

Budyko, M. I.: Evaporation under Natural Conditions, Gidrometeoizdat, Leningrad, 1948, English translation by Isr. Program for Sci. Transl., Jerusalem, 1963.

Budyko, M. I. (Ed.): Climate and Life, translated from Russian by: Miller, D. H., Academic, San Diego, CA, USA, , 321-330, 1974.

Burn, D. H. and Hesch, N. M.: Trends in evaporation for the Canadian Prairies, J. Hydrol., 336(1-2), 61-73, 2007.

Chahine, T. M.: The hydrological cycle and its influence on climate, Nature, 239, 373-381, 1992.

Chattopadhyay, N. and Hulme, M.: Evaporation and potential evapotranspiration in India under conditions of recent and future climate change, Agr. For. Meteorol., 87(1), 55-73, 1997.

Chen, D., Gao, G., Xu, C.-Y., Guo, J., and Ren, G.: Comparison of the Thornthwaite method and pan data with the standard Penman-Monteith estimates of reference evapotranspiration in China, Clim. Res., 28, 123-132, 2005.

Cohen, S., Ianetz, A., and Stanhill, G.: Evaporative climate changes at Bet Dagan, Israel, 1964-1998, Agricultural and Forest Meteorology, 111(2), 83-91, 2002.

Gifford, R. M., Roderick, M., and Farquhar, G. D.: Evaporative demand: does it increase with global warming? Global Change Newsletter 69, 32-23, online available at: http://www.rsbs.anu. edu.au/ResearchGroups/EBG/index.php, 2007.

IPCC: Climate Change 2007: The Physical Science Basis. Contribution of Working Group I to the Fourth Assessment, Cambridge University Press, New York, USA, 4-5, 2007.

Liu, B. H., Xu, M., Mark, H., Henderson, M., and Gong W.: A spatial analysis of pan evaporation trends in China, 1955-2000, J. Geophys. Res., 109, D15102, doi:10.1029/2004JD004511, 2004.
Maidment, D. R. (Ed.): Handbook of Hydrology, McGRAW-HILL, INC., 1. 19.17-19.18, 1993.

Moonen, A. C., Ercoli, L., Mariotti, M., and Masoni A.: Climate change in Italy indicated by agrometeorological indices over 122 years, Agr. For. Meteorol., 111, 13-27, 2002.

Morton, F. I.: Climatological estimates of evapotranspiration, J. Hydraul. Div. Am. Soc. Civ. Eng., 102(HY3), 275-291, 1976.

Morton, F. I.: Operational estimates of areal evapotranspiration and their significance to the science and practice of hydrology, J. Hydrol., 66, 1-76, 1983.

McVicar, T. R., Li, L. T., Van Niel, T. G., et al.: Spatially Distributing 21 Years of Monthly Hydrometeorological Data in China: Spatio-Temporal Analysis of FAO-56 Crop Reference Evapotranspiration and Pan Evaporation in the Context of Climate Change. CSIRO Land and Water Technical Report 8/05, Canberra, Australia, 316 pp., 2005

Oki, T. and Kanae, S.: Global hydrological cycles and world water resources, Science, 313, 1068-1072, 2006.

Peterson, T. C., Golubev, V. S., and Groisman, P. Y.: Evaporation losing its strength, Nature, 377, 687-688, 1995.

Pinker, R. T., Zhang, B., and Dutton, E. G.: Do satellites detect trends in surface solar radiation? Science, 308, 850-854, 2005.

Quintana-Gomez, R.: Changes in evaporation patterns detected in northernmost South America, Homogeneity testing, Proc. Seventh Int. Meeting on Statistical Climatology, Whisler, BC, Canada, NRCSE, 25-29, 1998.

Ren, G. and Guo, J.: Change in pan evaporation and the influential factors over China: 1956-2000, Journal of Natural Resources, 2006, 21(01), 31-44.

Ren, G. Y., Zhou, Y. Q., Chu, Z. Y., et al.: Urbanization effects on observed surface air temperature trends in North China, J. Clim., 21(6), 1333-1348, 2008.

Roderick, M. L. and Farquhar, G. D.: The cause of decreased pan evaporation over the past 50 years, Science, 298(15), 1410-1411, 2002.

Roderick, M. L. and Farquhar, G. D.: Changes in Australian pan evaporation from 1970 to 2002, Int. J. Climatol, 24, 1077-1090, 2004.

Roderick, M. L. and Farquhar, G. D.: Changes in New Zealand pan evaporation since the 1970s, Int. J. Climatol, 25, 2031-2039, doi:10.1002/joc.1262, 2005.

Sartori, E. There are no paradoxes among the evaporation, rainfall, temperatures and radiation over the last 30 to 50 years, and there is a new hydrological cycle, online available at: http: //noparadoxes.tripod.com $\rangle, 2006$.

Stanhill, G. and Cohen, S.: Global dimming: a review of the evidence for a widespread and significant reduction in global radiation with discussion of its probable causes and possible agricultural consequences, Agr. For. Meteorol., 107(4), 255-278, 2001.

Sun, L. and Wu, G. X.: Influence of land evapotranspiration on climate variations, Science in China (Series D), 44, 838-846, 2001.

Tebakari, T., Yoshitani, J., and Suvanpimol, C.: Time-Space Trend Analysis in Pan Evaporation over Kingdom of Thailand, J. Hydrol. Eng., 10(3), 205-215, 2005.

Thomas, A.: Spatial and temporal characteristics of potential evapotranspiration trends over China, Int. J. Clim., 20, 381-396, 2000.

Wild, M., Gilgen, H., Roesch, A., Ohmura, A., Long, C. N., Dutton, E. G., Forgan, B., Kallis, A., Russak, V., and Tsvetkov, A.: From Dimming to Brightening: Decadal Changes in Solar Radiation at 
Earth's Surface, Science, 308, 847-850, 2005.

Wu, S., Yin, Y., Zheng, D., and Yang, Q.: Moisture conditions and climate trends in China during the period 1971-2000, Int. J. Clim., 26(2), 193-206, 2006

Xu, M., Chang, C. P., Fu, C., Qi, Y., Robock, A., Robinson, D., and Zhang, H.: Steady decline of east Asian monsoon winds, 19692000: Evidence from direct ground measurements of wind speed, J. Geophys. Res., 111, D24111, doi:10.1029/2006JD007337, 2006.

Yang, D. W., Sun, F. B., Liu, Z. Y., Cong, Z. T., and Lei, Z. D.: Interpreting the complementary relationship in non-humid environments based on the Budyko and Penman hypotheses, Geophys. Res. Lett., 33, L18402, 2006.
Yang, D. W., Sun, F, B., Liu, Z. Y., Cong, Z. T., NI, G. H., and Lei, Z. D.: Analyzing spatial and temporal variability of annual water-energy balance in non-humid regions of China using the Budyko hypothesis, Water Resour. Res., 43, W04426, doi:10.1029/2006WR005224, 2007.

Yao, H. X., Terakawa, A., and Hashino, M.: Predicting future changes in climate and evaporation by a stepwise regression method, IAHS Publication (International Association of Hydrological Sciences), n 240, Symp 1: Sustainability of Water Resources under Increasing Uncertainty, 339-346, 1997.

Yue, S., Campbell, P. and Pilon, P.: Long-term water balance analysis using the complementary relationship areal evapotranspiration model, in: CSCE 16th Canadian Hydrotechnical Conference, Burlington, Ontario, Canada, 22-24 October, 2003. 